Jurnal ELTIKOM, Vol. 2, No. 2, Desember 2018, hal. 87-93 ISSN 2598-3245 (Print), ISSN 2598-3288 (Online)

Tersedia online di http://eltikom.poliban.ac.id DOI : http://doi.org/10.31961/eltikom.v2i2.48

\title{
SISTEM MONITORING KEHADIRAN SISWA MENGGUNAKAN NODEMCU PADA SEPATU YANG TERHUBUNG PADA SERVER PEMANTAUAN KEHADIRAN SISWA
}

\author{
Agus Setiyo Budi Nugroho'), Talitha Almira ${ }^{2)}$, Akhdiat Qudratullah ${ }^{3)}$, Akhmad Saufi ${ }^{4)}$ \\ ${ }^{1,2,4)}$ Politeknik Negeri Banjarmasin \\ ${ }^{3)}$ Universitas Muhammadiyah Malang \\ e-mail: agus_sbn@poliban.ac.id ${ }^{1)}$, almiratalitha@gmail.com²), akhdiatqudratullah13@gmail.com ${ }^{3)}$, \\ saufihassya @gmail.com ${ }^{4)}$
}

\begin{abstract}
School is a formal institution that is a means to get learning through guidance provided by educators both academic and non-academic education. Considering the frequent occurrence of disciplinary norms deviations among high school students (SMA), the deviation in question is ditching when the lesson takes place. The results of a survey conducted on 75 respondents from similar high school students in Banjarmasin showed that $52 \%$ of truant acts occur because of their own volition, while $48 \%$ are friends' invitations. Based on the problem created a tool called the santos (anti-skipping shoe system) which combines several technological concepts such as microcontrollers, network design, and information systems. Microcontroller consisting of NodeMCU, pressure sensor and battery will be installed on the student's shoes. If when the sensor is active, the NodeMCU is automatically connected to the signal in the form of a SSID (Service Set Identifier) emitted by the network access point. Each shoe connected to the network will be displayed on the information system that the student is not truant, but if the student's shoes are not connected to the network there will be two conditions, first if not connected before the first lesson then the system will send a telegram short message to the parents of the students, the second condition if it is not connected after the first lesson, the system will display the student's truant information. The more the santos are connected to the access point, the more traffic the network traffic process gets slower and slower. The maximum distance of the santos is $30 \mathrm{~m}$.
\end{abstract}

Keywords: ditching, the santos, network, information system, NodeMCU

\begin{abstract}
ABSTRAK
Sekolah merupakan lembaga formal yang menjadi sarana untuk mendapatkan pembelajaran melalui bimbingan yang diberikan oleh tenaga pendidik baik pendidikan akademik maupun non akademik. Mengingat sering terjadinya penyimpangan norma disiplin pada kalangan siswa Sekolah Menengah Atas (SMA), penyimpangan yang dimaksud adalah membolos saat jam pelajaran berlangsung. Hasil survei yang dilakukan pada 75 orang responden yang berasal dari siswa SMA sederajat di Banjarmasin menunjukkan 52\% tindakan membolos terjadi karena kemauan sendiri, sedangkan 48\% merupakan ajakan teman. Berdasarkan pada masalah tersebut diciptkanlah alat bernama si santos (sistem sepatu anti bolos) yang menggabungkan beberapa konsep teknologi seperti mikrokontroller, desain jaringan, serta sistem informasi. Mikrokontroller yang terdiri dari NodeMCU, sensor tekanan serta baterai akan dipasang pada sepatu siswa. Apabila saat sensor aktif maka NodeMCU secara otomatis terhubung pada sinyal dalam bentuk ssid (Service Set Identifier) yang dipancarkan oleh access point jaringan. Setiap sepatu yang terhubung ke jaringan akan ditampilkan pada sistem informasi bahwa siswa tersebut tidak dalam keadaan membolos, namun apabila sepatu siswa tidak terhubung ke jaringan akan terdapat dua kondisi, pertama jika tidak terhubung sebelum jam pelajaran pertama maka sistem akan mengirimkan pesan singkat melalui telegram kepada orang tua siswa, kondisi kedua jika tidak terhubung setelah jam pelajaran pertama maka sistem akan menampilkan informasi siswa membolos. Semakin banyak si santos yang terkoneksi dengan access point, maka proses lalu lintas jaringan semakin padat dan lamban. Jarak maksimal si santos adalah $30 \mathrm{~m}$.
\end{abstract}

Kata Kunci: membolos, si santos, jaringan, sistem informasi, NodeMCU 


\section{I.PENDAHULUAN}

$\mathrm{K}$ EHIDUPAN manusia tidak dapat dipisahkan dari bidang pendidikan. Pendidikan memiliki peran yang sangat penting bagi kehidupan manusia. Salah satu sarana dibidang pendidikan adalah sekolah. Sekolah merupakan suatu lembaga pendidikan formal yang memiliki berbagai macam mata pelajaran, dan setiap mata pelajaran yang diajarkan tentunya memuat berbagai bentuk pendidikan karakter [1]. Nilai karakter yang perlu dikembangkan adalah disiplin. Nilai karakter disiplin sangat penting dimiliki oleh manusia agar kemudian muncul nilai-nilai karakter yang baik lainnya. Pentingnya penguatan nilai karakter disiplin didasarkan pada alasan bahwa sekarang banyak terjadi perilaku menyimpang yang bertentangan dengan norma kedisiplinan [2]. Dunia pendidikan khususnya sekolah memiliki peran penting dalam medukung perkembangan anak secara optimal, mengingat banyaknya peristiwa yang menunjukkan terjadinya krisis moral baik di kalangan anak-anak, remaja, maupun orang tua. Salah satu contoh krisis moral yang terjadi pada siswa SMA yaitu membolos saat berlangsungnya jam pelajaran. Membolos adalah tindakan pergi meninggalkan sekolah tanpa alasan yang tepat dalam jam pelajaran dan tidak meminta izin terlebih dahulu kepada pihak sekolah [3].

Berdasarkan banyaknya kasus bolos pada jam pelajaran maka penyusun ingin mengajukan sebuah sistem baru yang mudah diterapkan yaitu si santos (sistem sepatu anti bolos) untuk melakukan pengawasan kehadiran siswa guna meningkatkan kedisiplinan berbasis mikrokontroller NodeMCU menggunakan jaringan nirkabel. Hal ini diharapkan dapat meningkatkan kedisiplinan siswa serta mengurangi kasus bolos pada jam pelajaran dan memfasilitasi akses yang mudah bagi guru untuk melakukan absensi.

\section{II.METODE PENELITIAN}

\section{A. Analisa Kebutuhan}

Mengumpulkan kebutuhan secara lengkap kemudian dianalisis, dan didefinisikan kebutuhan yang harus dipenuhi oleh program yang akan dibangun. Melakukan analisa terhadap hasil survei perlengkapan sekolah apa yang tidak mungkin digunakan siswa pada saat ke sekolah, dan warna sepatu yang digunakan siswa kesekolah. Serta melakukan studi literature, yaitu :

Mengenai absensi kehadiran siswa, absensi siswa di sekolah adalah kehadiran, dan keikutsertaan siswa secara fisik, dan mental terhadap aktivitas sekolah pada jam-jam efektif di sekolah [4]. Upaya pihak sekolah selama ini melakukan proses absensi secara umum dengan cara melakukan pemanggilan nama siswa satu persatu. Kemudian siswa melakukan konfirmasi kehadiran dengan mengangkat tangan serta menjawab "ada" setelah namanya dipanggil [5]. Hal ini dinilai kurang efektif karena dapat dimanfaatkan oleh siswa untuk keluar kelas pada saat proses belajar mengajar tanpa sepengetahuan guru yang bersangkutan dan tidak kembali lagi ke kelas. Sekolah juga tidak dapat mendeteksi kehadiran siswa yang keluar sekolah pada saat jam pelajaran kosong.

Menyangkut seluruh teori komunikasi jaringan wireless. Wireless merupakan teknologi yang digunakan untuk mentransmisikan data yang berjalan pada jaringan komputer tanpa penggunaan kabel dengan menggunakan infrastruktur dan media transmisi yang baru, melalui gelombang radio (Rumalutur, 2014). WiFi merupakan bentuk pemanfaatan teknologi Wireless Local Area Network (WLAN) pada lokasi-lokasi publik dengan standar pengambangan IEEE 802.11 antara lain IEEE 802.11.b; 802.11.a; dan 802.11.g [6].

Penggunaan NODEMCU. NodeMCU merupakan salah satu firmware modul ESP8266 yang bersifat open-source dan terdapat development kit untuk memudahkan membangun prototipe produk Internet of Things (IoT) dengan menggunakan bahasa pemograman Lua [7].

Website merupakan tempat penyimpanan data dan informasi tertentu yang di dalamnya terdapat fasilitas hypertext yang mampu menampilkan data berupa teks, gambar, suara, animasi, grafik dan multimedia lainnya. Dimana data-data tersebut saling berhubungan antara satu dengan lainnya. Data tersebut dapat dibaca melalui web browser seperti Mozilla Firefox, Google Chrome, maupun Microsoft Edge. Website terdapat halaman front end dan back end. Halaman front end adalah halaman yang bisa diakses oleh semua orang, sedangkan halaman back end adalah halaman yang hanya bisa diakses oleh orang yang diberikan hak akses tertentu [8].

Basis data yang digunakan adalah MYSQL. MySQL adalah sebuah program database server yang mampu menerima dan mengirimkan datanya dengan sangat cepat, multi user, serta menggunakan perintah standar SQL (Structured Query Language) [9]. 
Telegram terdiri dari dua bentuk API, yaitu klien IM Telegram dan Telegram Bot Api. Klien IM Telegram merupakan API yang dimana semua orang dapat menjadi pengembang klien, sehingga apabila ingin mengembangkan kembali tidak perlu memulai dari awal lagi. Sedangkan Telegram Bot API memungkinkan semua orang untuk membuat bot yang akan membalas semua penggunanya jika mengirimkan pesan perintah yang dapat diterima oleh Bot tersebut [10].

\section{B. Desain Sistem}

Tahap ini dilakukan sebelum melakukan proses pengkodean terhadap mikrokontroller dan sistem yang ingin dibuat. Jenis sepatu yang digunakan adalah sepatu sneakers dan didukung NodeMCU sebagai mikrokontrollernya, sensor peizo (tekanan), batterai lippo satu cell, female connector + board, serta kabel yang berjenis male female. Jaringan yang menghubungkan sepatu ke sistem menggunakan router mikrotik dan server, switch, AP (Access Point), dan kabel jaringan (straight). Sedangkan software yang pendukung pembuatan sistem adalah apache server untuk menjalankan file PHP, MYSQL untuk database dan editor Notepad++. Gambar 1 merupakan alur koneksi si santos, Gambar 2 desain arsitektur jaringan yang akan digunakan, Gambar 3 rangkaian yang digunakan pada mikrokontroller.

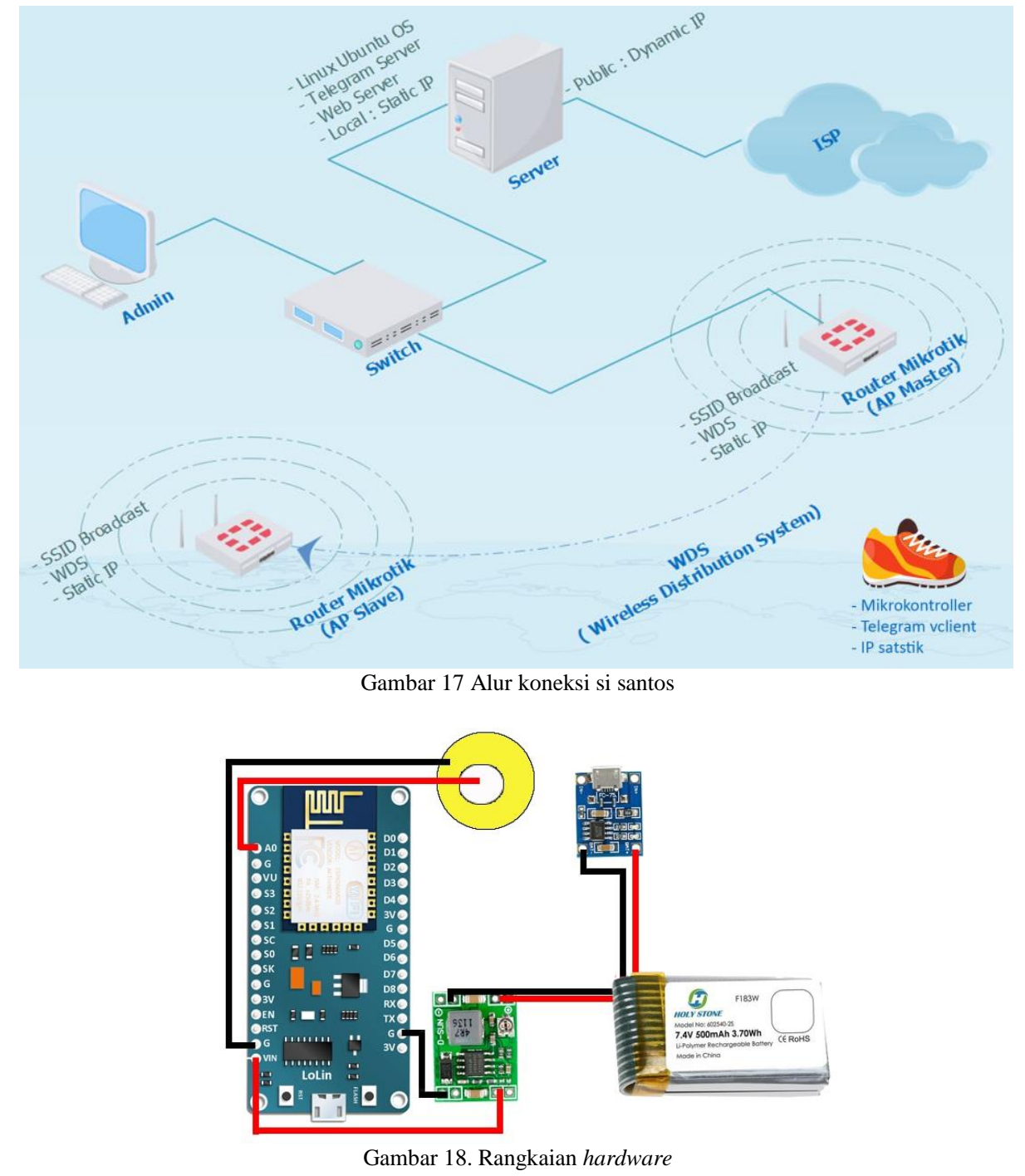

\section{Antarmuka Sistem}

Rancangan antarmuka sistem bagian front end. Dapat dilihat pada Gambar 3 di bawah ini. Terdapat 4 bagian utama pada antar muka. Pertama adalah header yang berisi logo dan nama sekolah. Bagian kedua adalah bagian title menggunakan nama sekolah serta alamat lengkap. Bagian ketiga adalah tabel tracking siswa. Dan bagian keempat adalah bagian footer. Dimana guru akan melihat status kehadiran siswa di bagian ini. Untuk bagian antar muka admin akan ada menu tambahan untuk insert, update, dan delete data siswa seperti Gambar 4. 


\begin{tabular}{|c|c|c|c|c|c|c|}
\hline \multicolumn{7}{|c|}{ 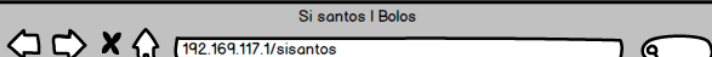 } \\
\hline \multicolumn{7}{|c|}{ Sistem Sepatu Anti Bolos SMK A Banjarmasin } \\
\hline \multicolumn{7}{|c|}{$\begin{array}{l}\text { Sekolah Menengah Ke juruan A Banjarmasin } \\
\mathrm{Jl} \text { Bridg. Hasan Basri Banjarmasin, (0811-2222-3332), admin@admin.schid }\end{array}$} \\
\hline \multicolumn{7}{|c|}{ Tracking Bolos (3, Juli 2018) } \\
\hline No & NIS & Nama Siswa & Jenis Kelamin & Kelas & waktu & Status \\
\hline 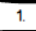 & R01 & Akhdiat Qudratullah & Loki-laki & RPL - 01 & $07: 30: 09$ & Hodir \\
\hline 2. & T05 & Akhmod Soufi & Loki-loki & TKJ .01 & $07: 3109$ & Hodir \\
\hline 3. & M32 & Tolitho Almira & Perempuan & MUL-01 & 07:30:10 & Hadir \\
\hline \multicolumn{7}{|c|}{ c 2018 Copy Right Si sontos I Politeknik Negeri Banjarmasin } \\
\hline & & & & & & $\underline{1}$ \\
\hline
\end{tabular}

Gambar 19. Front end sistem si santos

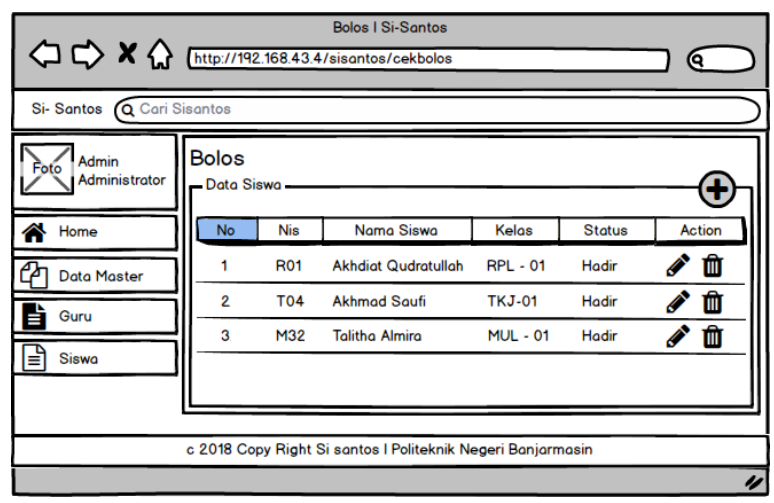

Gambar 20. Antarmuka sistem si santos

\section{III.HASIL DAN PEMBAHASAN}

\section{A. Aktifasi Si Santos}

Aktifasi si santos menggunakan sensor piezo, jika sensor di tekan, maka si santos akan aktif dan akan tidak aktif apabila sensor dilepas. Pada mikrokontroller di deklarasikan IP ((Internet Protocol Address) sebagai identitas masing-masing si santos. Untuk memperjelas uraian diatas dapat dilihat pada Gambar 5 dan 6.
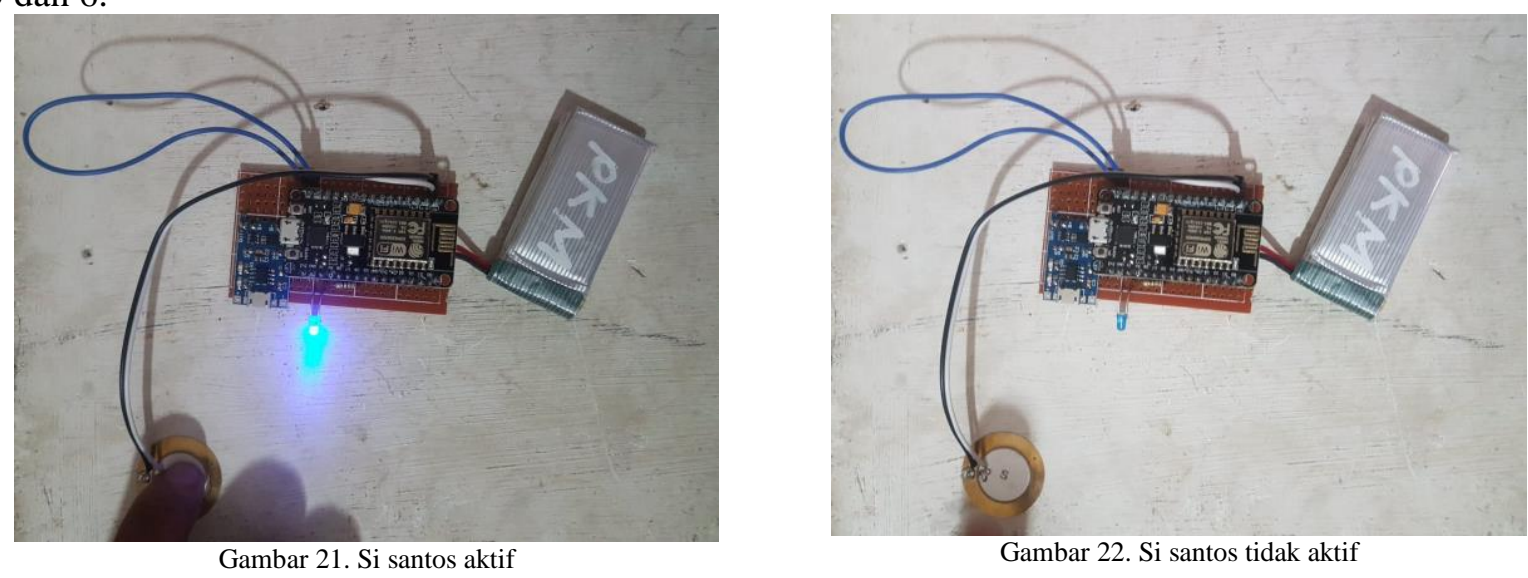

\section{B. Koneksi Si Santos dengan Access Point}

Si santos akan menyalakan LED berwarna biru apabila terkoneksi dengan akses poin. Sedangkan apabila si santos tidak terkoneksi, maka LED akan padam. Sebelum terkoneksi dengan akses point, si santos akan diberikan waktu selama lima detik untuk melakukan koneksi. Hal ini dilakukan untuk adanya selisih waktu koneksi sehingga mempercepat lalu lintaskoneksi si santos dengan akses poin. Seperti yang ditunjukkan pada Gambar 7 dan 8.

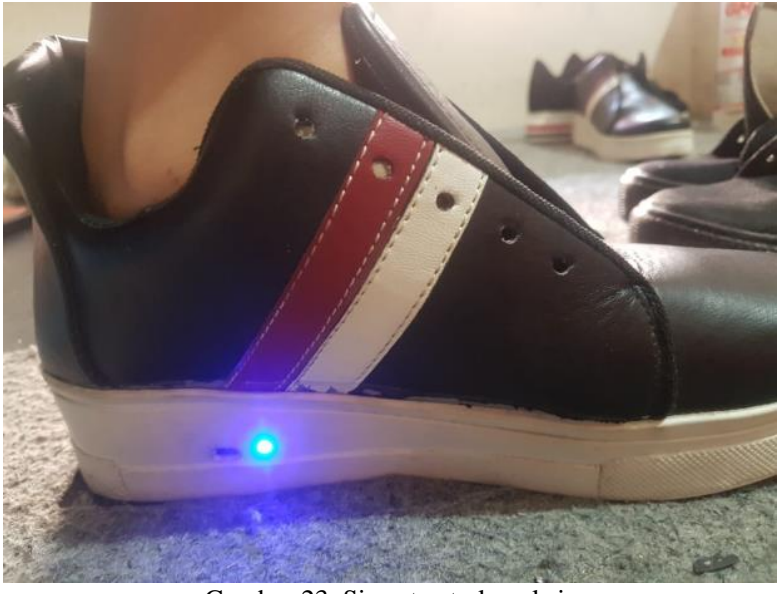

Gambar 23. Si santos terkoneksi

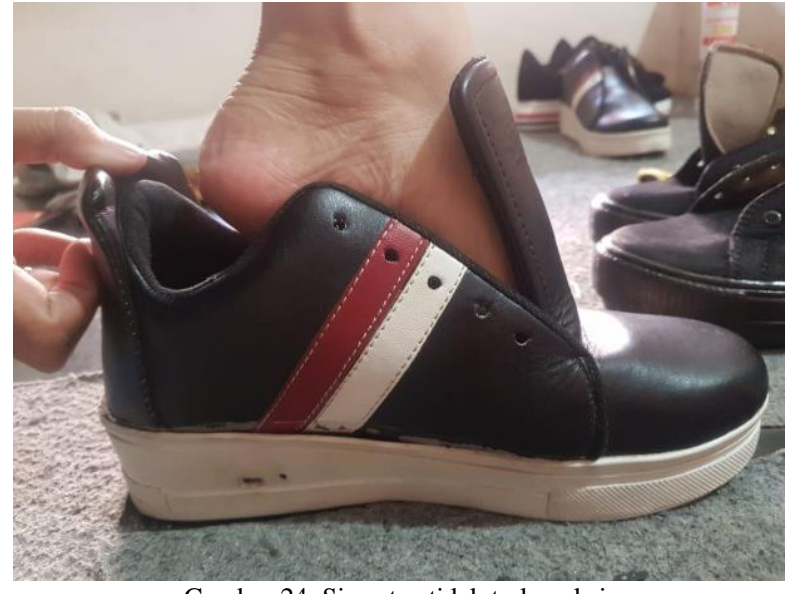

Gambar 24. Si santos tidak terkoneksi 


\section{Pengujian Deteksi Si Santos Oleh Aplikasi Server}

Dibawah ini merupakan hasil pengujian sistem informasi menggunakan tiga buah si santos. Si santos yang terkoneksi dengan akses poin, akan menghasilkan output berwarna hijau, sedangkan yang tidak terkoneksi akan menghasilkan output berwarna merah dapat dilihat pada Gambar 9.

\section{SMU Sistem Sepatu Anti Bolos SMK A Banjarmasin}

\section{SMK Sekolah Menengah Kejuruan A Banjarmasin}

Tracking Bolos (03 July 2018)

Kelas RPL3 - 2008
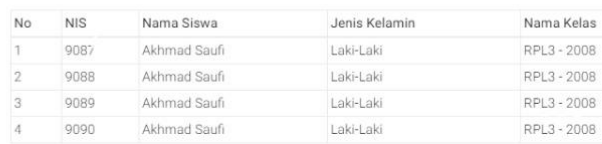

Waktu

2018-07-03 16:21:08

2018-07-03 16:21:08

2018-07-03 16:21:08
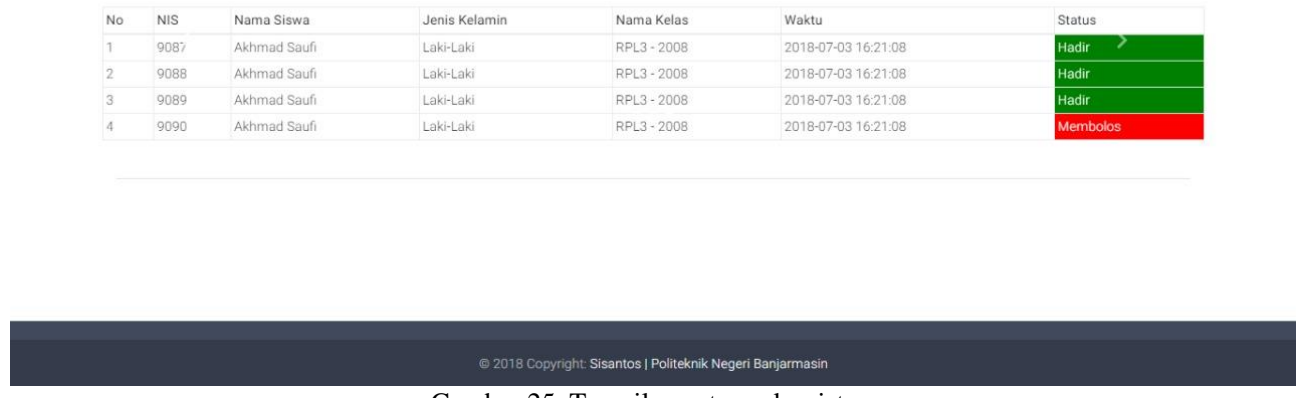

Gambar 25. Tampilan antarmuka sistem

\section{Data Kehadiran Siswa}

Setelah proses monitoring dilakukan, admin dapat mencetak data status kehadiran siswa. Dimana admin dapat memilih tanggal data kehadiran siswa yang dicetak. Kemudian admin dapat mencetak data tersebut, dan akan mencetak data sesuai data tanggal yang di inputkan. Uraian dapat dilihat pada Gambar 10 dan 11.

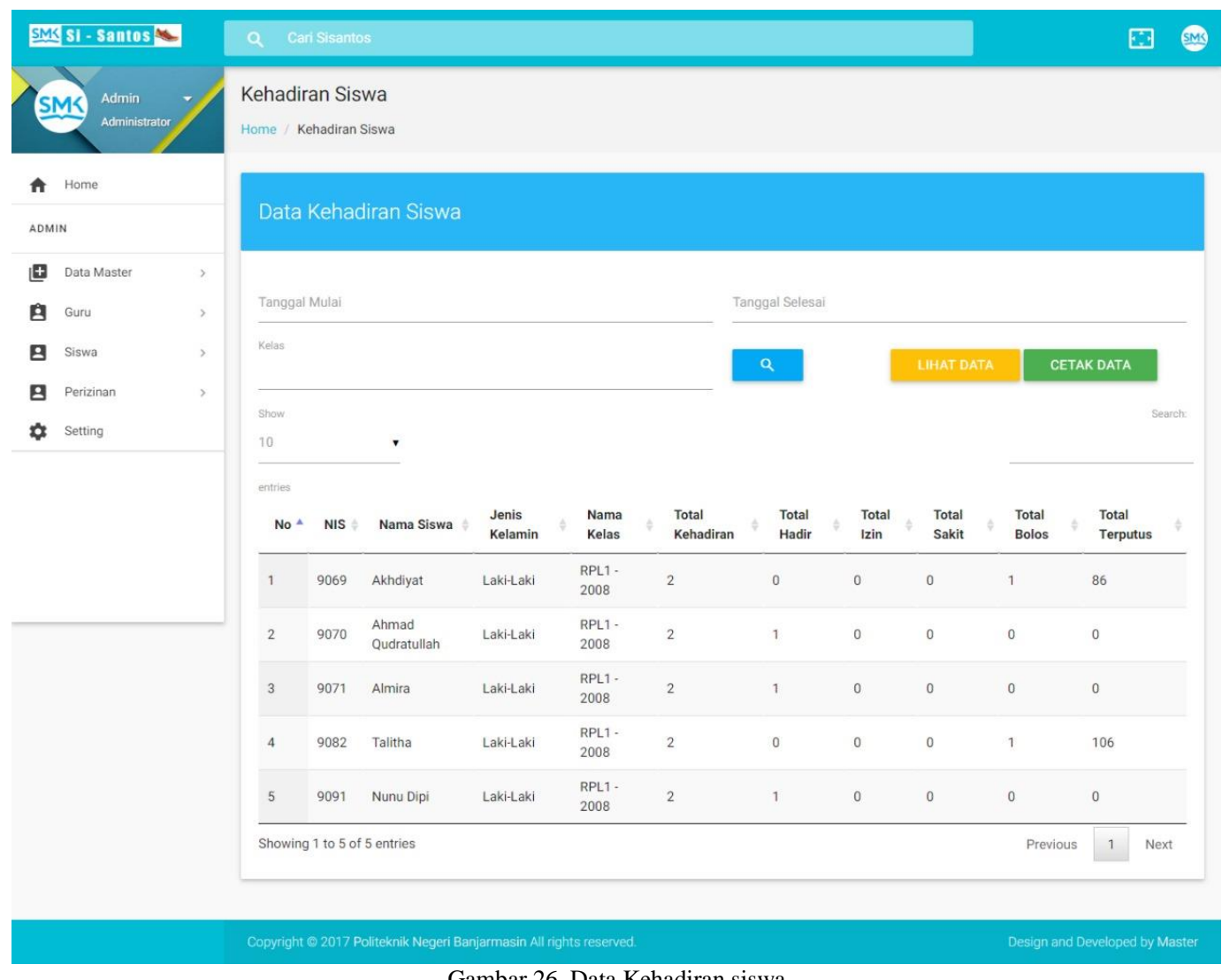

Gambar 26. Data Kehadiran siswa 


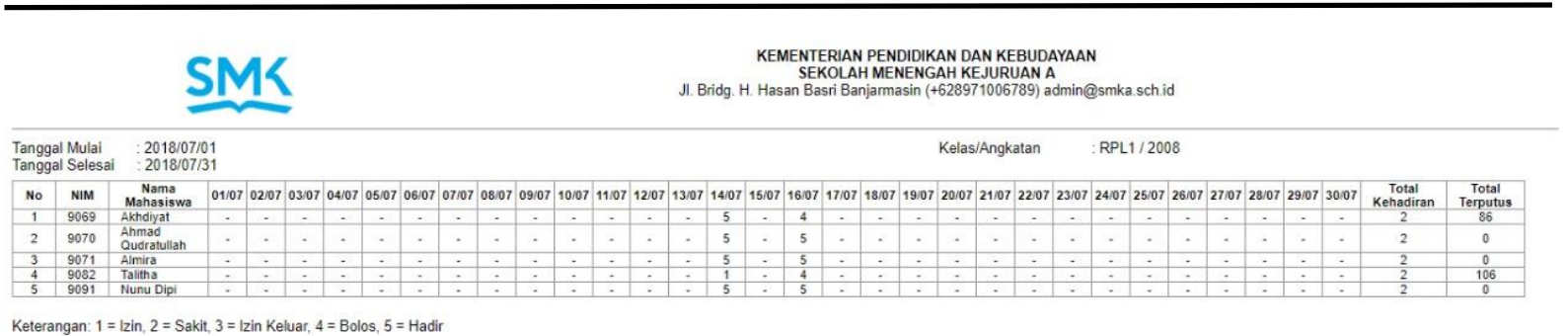

Gambar 27. Hasil data yang dicetak

\section{E. Hasil Pengiriman Pesan Melalui Telegram}

Gambar 11 merupakan hasil dari pengiriman pesan singkat otomatis dari sistem apabila siswa hadir di sekolah menggunakan aplikasi telegram. Pesan telegram dikirimkan pada orang tua siswa menggunakan nomer handphone orang tua yang telah di daftarkan pada database.

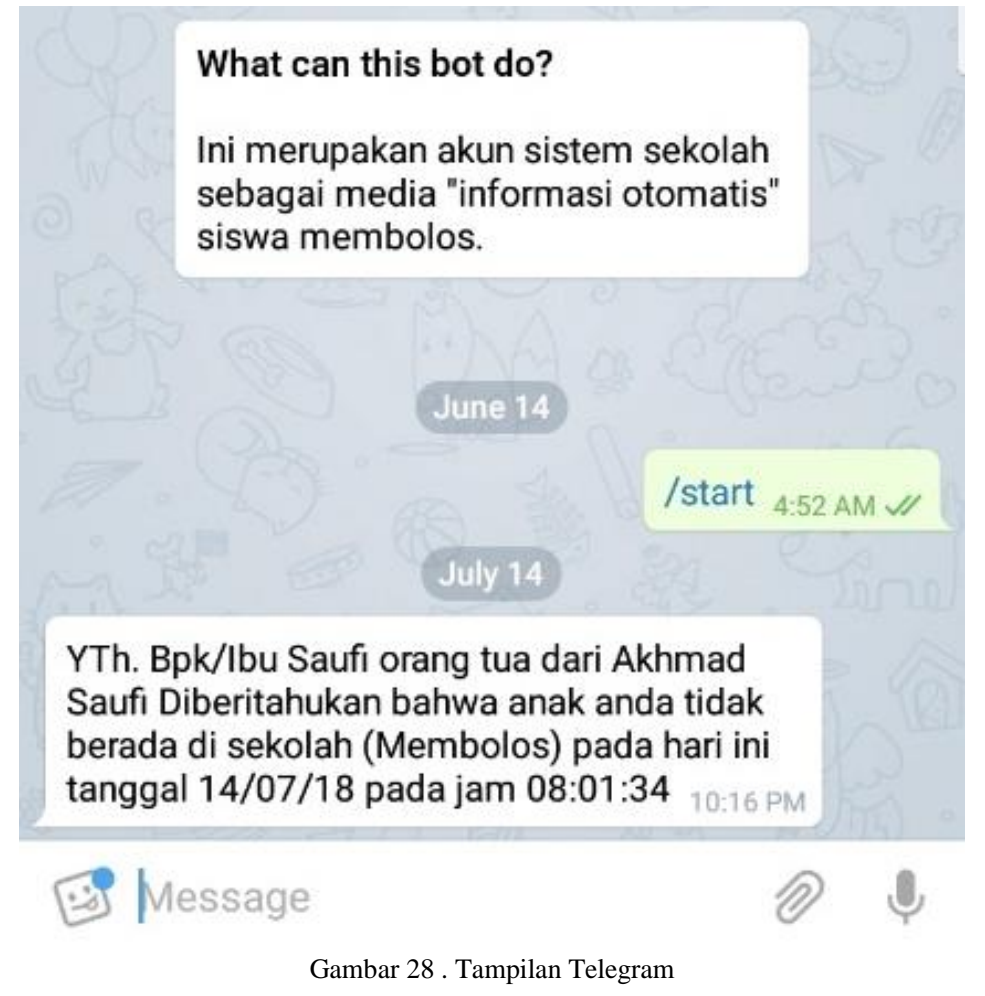

\section{F. Pengujian Koneksi Lebih Dari Satu Si Santos}

Pada pengujian ini dilakukan menggunakan tiga pasang sepatu dan menggunakan data yang telah terkoneksi pada access point selama satu menit. Perhitungan kecepatan proses koneksi menggunakan perhitungan rata-rata. Data pengujian dapat dilihat pada Tabel 1.

TABEL I

KECEPATAN KONEKSI

\begin{tabular}{lll}
\hline \multicolumn{2}{c}{ KECEPATAN KONEKSI } \\
\hline \hline No & Jumlah Sepatu & Kecepatan Proses \\
\hline 1. & Satu buah & $237 \mathrm{~ms}$ \\
2. & Dua buah & $325 \mathrm{~ms}$ \\
3. & Tiga Buah & $407 \mathrm{~ms}$ \\
\hline \hline
\end{tabular}

\section{G. Pengujian Jarak Koneksi Si Santos}

Pengujian jarak maksimal pada si santos adalah sejauh $30 \mathrm{~m}$ dari access point. Data diambil berdasarkan kecepatan rata-rata pada saat proses terhubungnya si santos dengan access point selama satu menit. Data jarak koneksi dapat dilihat pada Tabel 2. 
TABEL II

PENGUJIAN JARAK KONEKSI

\begin{tabular}{lll}
\hline \hline No & Jarak & Status Koneksi \\
\hline 1. & 5 meter & Sangat Kuat \\
2. & 10 meter & Sangat Kuat \\
3. & 15 meter & Cukup Kuat \\
4. & 20 meter & Kuat \\
5. & 25 meter & Kuat \\
6. & 30 meter & Lemah \\
7. & 35 meter & Cukup Lemah \\
8. & 40 meter & Sangat Lemah \\
9. & 50 meter & Sangat Lemah \\
\hline \hline
\end{tabular}

Keterangan kecepatan rata-rata status koneksi:

1. Sangat Kuat $=1-10 \mathrm{~ms}$

2. Kuat $=11-20 \mathrm{~ms}$

3. Cukup Kuat $=21-30 \mathrm{~ms}$

4. Lemah $=31-45 \mathrm{~ms}$

5. Cukup Lemah $=46-60 \mathrm{~ms}$

6. Sangat Lemah $=61-80 \mathrm{~ms}$

\section{IV.KESIMPULAN}

Monitoring keadiran siswa menggunakan NodeMCU yang dimana menggunakan sensor peizo untuk aktifasi awal agar si santos terhubung pada jaringan. Menggunakan LED sebagai indikator terhubungnya si santos dengan access point. Semakin banyak si santos yang terkoneksi dengan access point, maka proses lalu lintas jaringan semakin padat dan lamban. Jarak maksimal si santos adalah $30 \mathrm{~m}$.

\section{DAFTAR PUSTAKA}

[1] M. Andi Setiawan, "Mengatasi Perilaku Membolos Melalui Pendekatan Konseling Realita Pada Siswa Kelas VII Di MTS NU Ungaran," Suluh J. Bimbing. dan Konseling, vol. 2, no. April, pp. 22-28, 2016.

[2] W. Wuryandani, B. Maftuh, and D. Budimansyah, "Pendidikan Karakter Disiplin Sekolah Dasar," Cakrawala Pendidik., vol. 2, pp. 286$295,2014$.

[3] W. Graciani, "Perilaku Membolos Siswa (Studi Deskriptif Kualitatif tentang Perilaku Membolos Siswa di SMP Negeri 2 Delanggu, Kecamatan Delanggu, Kabupaten Klaten)," Universitas Sebelas Maret, 2011.

[4] R. Parlika, N. de S. Gama, A. E. Febrianto, and A. R. Hakim, "Sistem Absensi Sidik Jari Terintegrasi Sms Gateway Berbasis Desktop Menggunakan Visual Basic Dan MYSQL," vol. IX, pp. 7-14, 2014.

[5] Istri Sulistiyowati, "Perancangan Dan Implementasi Aplikasi Berbasis SMS Gateway Sebagai Media Informasi Absensi Siswa Di SMP Negeri 1 Tambak," Telematika, vol. 5, 2012.

[6] E. B. Purnomowati, "Integrasi Wireless Fidelity ( WiFi ) pada jaringan Universal Mobile Telecommunication System ( UMTS )," EECCIS, vol. II, no. 1, pp. 11-16, 2008.

[7] H. Yuliansyah, "Uji Kinerja Pengiriman Data Secara Wireless Menggunakan Modul ESP8266 Berbasis Rest Architecture," Electr. J. Rekayasa dan Teknol. Elektro, vol. 10, no. 2 (Mei 2016), pp. 68-77, 2016.

[8] A. A. Mahrus, Web Design \& Pemrograman Web, no. 21. 2010.

[9] W. S. E., A. Y. Wijaya, and R. Soelaiman, "Klasifikasi Citra Menggunakan Convolutional Neural Network (Cnn) Pada Caltech 101," J. Tek. ITS, vol. 5, no. 1, pp. 65-69, 2016.

[10] G. Sastrawangsa, "Pemanfaatan Telegram Bot Untuk Automatisasi Layanan Dan Informasi Mahasiswa Dalam Konsep Smart Campus," Konf. Nas. Sist. Inform., pp. 772-776, 2017. 